\title{
Emancipation: A Constant Theme in Kate Chopin's Short Stories
}

\author{
Florinda Boriçii Ph.D. Candidate
}

Doi:10.5901/jesr.2014.v4n4p248

Part-time Professor at University of Tirana, Albania

\begin{abstract}
Kate Chopin is an American author of the late nineteenth century, who started her career as a short story writer of the Local Color school, but soon moved on to the treatment of more timeless matters. She has written some of the boldest and best stories written in America before the 1960s. In her works we find a great variety of themes, some of which were taboo in her time. Themes such as alcohol, divorce, miscegenation and even female sexuality. But a constant theme throughout her whole oeuvre is emancipation. First as a spiritual emancipation and later also in the field of the senses. The Aim of this paper is to analyze this theme in several short stories written by Kate Chopin, where some of her strong female characters seek emancipation by defying conventions and deciding over their own lives.
\end{abstract}

\section{Introduction}

Kate Chopin was an American novelist and short-story writer who became known in the late nineteenth century. She started her career as a short story writer, in well-known periodicals as Vogue, the Century and the Atlantic. But apart from nearly one hundred short stories Kate Chopin has also written two novels, a play, various essays and literary reviews and some translations. After the publication of her two collections of short stories Bayou Folk (1894) and A Night in Acadie (1897) she was recognized nationally as an outstanding short story writer of the local color school. (Local Color refers to fiction that came to prominence in the USA in the late nineteenth century and was devoted to capturing the features and peculiarities of a particular locality and its inhabitants- their distinctive dialect, history and customs).

Her stories do indeed effectively evoke the atmosphere of her enchanting Southern localities. Yet her interest was not so much idyllic localism as what she termed in one of her essays "human existence in its subtle, complex, true meaning, stripped of the veil with witch ethical and conventional standards have draped it." So by being called an artist of local color she wasn't given the real credit she deserved. Today, however her reputation stands high. She is considered as the author of some of the boldest and best stories written in America before the 1960s. Some critics even consider her to be a predecessor of the feminist authors of the 20th century. Her stories treat all sorts of taboo subjects of her time such as miscegenation, divorce, alcohol, pregnancy, childbirth and even female sexuality. But almost a constant theme in most of her stories is "Emancipation". First as a spiritual emancipation and later also in the field of the senses.

Chopin started with this theme, perhaps unconsciously, when she was only eighteen years old, before she married and before she evinced any interest in a literary career, she wrote a little sketch entitled "Emancipation: A Life Fable". Years later when she turned to writing in earnest at the age of thirty-eight, after her husband's death, her life and experiences as a woman apparently affirmed the truths she expressed first in "Emancipation" and her development as a literary artist enabled her to transpose those truths into art with increasing skill until at last in the novel The Awakening, the fully artistic expression of her theme, became possible.

The 1869 or 1870 "Fable" describes an animal "born in a cage," who "opening his eyes upon Life... saw... confining walls." He thrives until one day someone accidentally leaves open the cage's door. He first reacts with fear, but the "Light" lures him with increasing force until at last the "spell of the Unknown" pulls him out altogether, "and with a bound he was gone" (Kate Chopin, The Complete Works of Kate Chopin [CW], Seyersted. ed. 2006, p. 37)

No longer protected by the cage, "On he rushes, ... wounding and tearing his sleek sides, seeing, smelling, touching of all things." Gone is the "invisible protecting hand," and the animal discovers that "hungering there is no food but such as he must seek and oftentimes fight for; and his limbs are weighted before he reaches the water that is good to his thirsting throat." He could return to the cage, but he does not: "So does he live, seeking, finding, joying and suffering. The door which accident had opened is open still, but the cage remains forever empty" (CW, p.37-38). The animal, rejecting security within the cage, embraces life with all its suffering and sorrows. The animal represents the humans, while the story mirrors man's fall from grace and the story of original sin from the Bible. The caged animal with all its needs met is like content Adam and Eve in paradise before the fall. After wisdom of good and evil is gained from Eve eating the apple, the couple is never able to go back to garden (i.e. cage) and they must experience suffering and labor 
like the animal does now to get his food and comforts.

After reading this sketch we find a startling similarity between this animal and many of the heroines in Kate Chopin's stories. Women who insist on freedom from traditional duties and limitations causing editors often to turn down many of her stories because her women characters were considered too passionate and emancipated. Her heroines usually live out their strong impulses. They try to defy conventions and to decide over their own lives. Kate Chopin herself saw and understood all aspects of the female psyche.

Kate Chopin's first woman character, Paula Von Stoltz of the short story "Wiser Than a God", is a young woman who works hard to become a concert pianist. She loves the rich George Breinard, but when he asks her to follow a calling that asks "only for the labor of loving" (CW, p.45), she replies that marriage does not enter into the "purpose of her life". George insists that he does not ask her to give up anything: she tells him, however that music to her is "something dearer than life, than riches, than love". This is too contrary to George's idea of a woman's role. In opposing the traditional female duties and limitations Paula is a female who wants to be active and refuses the passivity man means to impose on her. She insists on the active transcendence of a subject rather than the passive immanence of an object and who attempts to achieve an existentialist authenticity obtained through making a conscious choice, giving her own laws, realizing her essence and making herself her own destiny.

In the short story "A Shameful Affair", Mildred Orme, is another illustration of this type of woman. She rejects the role of the passive, innocent party who makes no advances in sexual relations and demands instead the responsibility of an active subject.

Lisa of the short story "The Going away of Liza" is Chopin's first heroine to live her husband and her reason is that she considers him commonplace and unable to give her the joys of existence which she craves for.

In the short story "The Maid of Saint Phillippe" the protagonist, Marianne, refuses to become a traditional housewife and joins the Cherokees for a hunter's life instead.

Eva Artless of "An embarrassing situation" the author's one-act comedy, also takes her life in her own hands. By suddenly visiting the man she admires, she puts him in a situation which can only be saved by that offer of marriage she is hoping for.

In the short story "The story of an Hour" where Chopin has given a startling picture of female self- assertion. Mrs. Mallard exclaims "Free! Free! Free! Body and soul free" (CW, p. 353) when she hears of her husband's sudden death. The story is a truly remarkable tale about a subdued wife's vision of living only for herself. "She saw a long procession of years to come that would belong to her absolutely... There would be no powerful will bending hers in that blind persistence with which men and women believe they have a right to impose a private will upon a fellow creature. A kind intention or a cruel intention made the act seem no less a crime as she looked upon it..." (CW, p. 353)

Kate Chopin has also treated in some of her stories woman's sexual emancipation.

Mme. Delisle of "A Lady of Bayou St. John", only at the last moment gives up her intention to desert her husband for a lover. In "A respectable Woman" the question of infidelity is left open.

In "The Storm" one of the most daring stories in American literature of the time that Kate Chopin didn't even try to publish during her lifetime. It was published after Chopin's death. Here the main character, Calixta, during a storm commits adultery, but instead of feeling guilty over an act considered a sin in her time, she feels liberated. At a time when women were expected to behave properly that is to have limited sexual desire and to act passively Calixta goes against her society's standard of virtue. She chooses to give in to her emotions. Like the real storm of the story, Calixta becomes a force of nature who seeks fulfillment outside her home.

And at last the fully artistic expression of the theme of emancipation can be seen in her masterpiece, the novel The Awakening, which is often labeled as an early feminist novel and a bold piece of fiction. The main character, Edna Pontellier, a married woman and the mother of two children, has awakened in full to an imperative craving for independence, for clarity and self-knowledge. She seeks self-fulfillment and sexual gratification outside her home. Edna fights against the societal structures that force her to be defined by her title as just a wife and a mother. She realizes she is unable to live as the inessential adjunct to a man, as the object over which man rules. "I give myself where I choose," (CW, 2006, p.992) she declares when Robert, her young man, suggests he might ask her husband to set her free. What she craves to be is an independent subject, to dictate her own destiny. "I would give up the inessential, I would give my money, I would give my life for my children; but I wouldn't give myself" (CW, p. 929) Edna explains to her friend. In other words, to her it is more important to have a self than to live. But seeing that we are pawns in the hands of procreational nature, and how patriarchal society condemns particularly a freedom-seeking woman who neglects her children, she inevitably finds her power to dictate her own life to be illusory. Wanting her own way at all cost, she chooses the supreme exertion of her freedom: she takes her own life. Mrs. Pontellier's defeat lies in the fact that she cannot integrate her demands with those of society. Her victory is her awakening to consciousness and authenticity. 
In conclusion, though Chopin describes many women in her stories who are perfectly happy in conventional marriage, she has also a number of heroines who demand freedom, emancipation and an authentic existence. Chopin felt that a woman should be allowed the role she wants. She presents her stories objectively and refrains from all moralizing. By making emancipation as a constant theme in her works Chopin challenged assumptions about the roles and restrictions of women in her society and laid claim to new freedoms for women. That is why she is highly praised nowadays as a predecessor of the twentieth century feminism.

\section{References}

Chopin, Kate, (2006) The Complete Works of Kate Chopin, ed. Per Seyersted, Baton Rouge, La.: Louisiana state University Press Seyersted, Per (ed), (1990), Kate Chopin: A Critical Biography, Baton Rouge, La.: Louisiana state University Press 